\title{
EDITORIAL STAFF BIOS
}

EDITOR-IN-CHIEF

Marissa Esthimer is a second-year Master of Public Policy candidate at the

Trachtenberg School, focusing on immigration and social policy. Originally from Buffalo, NY, she graduated from Cornell University in 2012 with a BA in government and anthropology and a minor in international relations. She works as an analyst for the federal government and previously spent nearly five years working as an editor and communications professional at the Migration Policy Institute, a nonpartisan think tank focused on the movement of people across borders. With her degree, she hopes to evaluate policies impacting minority and low-income communities. In her spare time, she enjoys attending live performances, trying new restaurants, and playing with her cat.

\section{MANAGING EDITOR}

Claire Oto is a second-year Master of Public Policy candidate at the Trachtenberg School, focusing on national security and defense policy. Originally from Sacramento, CA, she graduated from UC San Diego in 2017 with a BA in comparative politics and minors in European history and photography. She currently works on the communications and public affairs team for the Department of Energy's Office of Science. 


\section{ASSOCIATE EDITORS}

Kendall Banks is a first-year Master of Public Administration candidate at the Trachtenberg School, concentrating in program evaluation. Originally from the suburbs of New York City, Kendall graduated from Cornell University with a Bachelor's in human development, and has since had a variety of experiences in the private and public sectors. Kendall came to Washington, DC to pursue her MPA after four years living and working in various nonprofit and USAID projects in Central America and Mexico. She currently works as an Analyst Intern at the U.S. Government Accountability Office. When not studying, Kendall loves to travel, salsa dance, ride horses, and read whatever she can get her hands on!

Erik Chen is a first-year Master of Public Administration student at the Trachtenberg School. Born in Queens, Erik carries a big-city spirit, experiencing stints in Chicago and Boston during the formative years of his childhood before returning to NYC for college. He attended NYU where he received his BA in economics and minor in computer science. Prior to moving to DC to pursue his studies, Erik spent two years working in the private sector supporting the Municipal Markets trading desk at Bank of America Merrill Lynch. He is currently an intern at HealthHIV focusing on LGBT Health policy and advocacy. In his free time, Erik loves to cook, explore neighborhoods, and train in mixed martial arts.

David Gellman is a first-year Master of Public Administration candidate focusing on politics, policy, and administration at the Trachtenberg School. Originally from Miami, FL, he graduated from Georgetown University with a BA in government and a minor in Spanish. He most recently worked in a boutique government affairs firm on K Street and spent several years as a legislative staffer on Capitol Hill. He enjoys travel, food, and watching basketball when he isn't studying.

Carly Gordon is a second-year Master of Public Administration student with academic interests in higher education policy, program evaluation, and community development. After graduating from the University of Virginia with a BA in Spanish and psychology (and a minor in global sustainability), she stayed in Charlottesville to serve locally with AmeriCorps. As an adviser with the Virginia College Advising Corps program, she worked on addressing the widening gap in college access for low income, first generation, and other underrepresented students. When she isn't petting doggos, baking, or exploring DC, she works as a Graduate Intern at Excelencia in Education elevating evidence-based programs that accelerate Latinx achievement.

Miranda Hines is a first-year Master of Public Policy candidate at the Trachtenberg School. She graduated from Washington University in St. Louis with a BA in political science and second major in English literature. Outside of class, Miranda is currently a graduate assistant in the Trachtenberg School and a member of the GW-USIP Mentorship Program. 
Andrew Miller is a second-year Master of Public Administration candidate with a concentration in budget and public finance at the Trachtenberg School. He grew up in Fairfax, VA before graduating in 2015 with a BA in public policy and international relations from the University of Delaware (go blue hens!). Andrew has worked in the United States Senate since 2015 and is also involved with the Trachtenberg Student Organization at GW.

Emma Pellerin is a first-year Master of Public Policy candidate focusing on education policy. A native of southeastern Connecticut, she graduated from the College of the Holy Cross in 2012 with a degree in English and political science. She joined the 2012 Teach for America-Baltimore corps as a ninth grade English teacher and earned her Master's degree in secondary education from Johns Hopkins University School of Education in 2014. Since leaving the classroom, Emma has worked as an organizer with Hillary for America and Educators for Excellence. She currently works on the operations team at LearnZillion and enjoys reading, cooking, and knitting in her spare time.

Jackie Wheeler is a first-year Master of Public Administration candidate at the Trachtenberg School. Originally from a small town outside of Charlotte, North Carolina, Jackie graduated from the University of Washington in 2013 with a BA in politics, philosophy, and economics. Before moving to Washington, DC for graduate school, she was an Elections Administrator for the Washington Office of the Secretary of State in Olympia, WA. Jackie hopes to use her degree to develop voter-centric election policy that ensures elections are fair, accurate, and accessible. During her free time, she enjoys rooting for Seattle sports teams, hiking, and visiting family in North Carolina and Washington State.

\section{- LAYOUT EDITOR}

Ellen Wang is a second-year Master's student in the Environmental Resource Policy (ENRP) program at the Trachtenberg School. She graduated from the University of Cincinnati's school of Design Architecture Art and Planning with a BS in graphic communication design in 2017. She is working to combine complex ideas and concepts with better visual communication and storytelling methods. Ellen loves food, comics, board games, and travelling. 